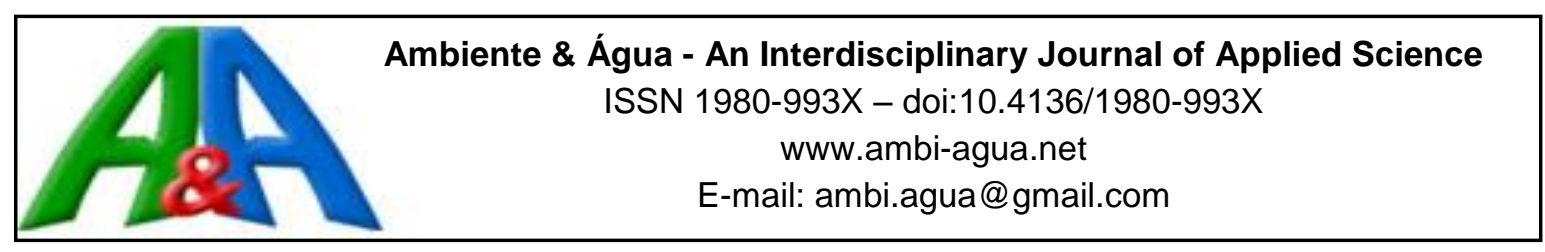

\title{
Impact of spineless cactus cultivation (O. Ficus-indica) on the thermal characteristics of soil
}

\author{
ARTICLES doi:10.4136/ambi-agua.2148
}

Received: 13 Jun. 2017; Accepted: 12 Dec. 2017

Willames de Albuquerque Soares

Universidade de Pernambuco (UPE), Recife, PE, Brasil

Escola Politécnica de Pernambuco (POLI). E-mail: was@poli.br

*Corresponding author

\begin{abstract}
Temperature is a fundamentally important factor for understanding the physical, chemical, and biological processes that occur in soil. However, there are few studies in the Brazilian semiarid zone that seek to understand how soil degradation affects its thermal characteristics. The objective of this study was to evaluate the influence of cultivation techniques on the thermal characterization of soil, using the model proposed by Johansen. The study was conducted in the Agreste region of the state of Pernambuco, Brazil on two plots of land, one with native vegetation (Caatinga) and the other with spineless cactus ( $O$. ficus - indica). It was observed that the procedures used to prepare the soil for cultivation of spineless cactus caused a reduction in the capacity to transmit the surface temperature to the interior of the soil. Changes in the physical properties of the soil required for cultivation resulted in a reduction in the average value of the volumetric heat capacity of about $22 \%$; an increase of approximately $5 \%$ in the average volumetric heat capacity and a $26 \%$ increase in the thermal diffusivity of the soil, as well as a reduction of approximately $50 \%$ in the heat flux from the surface of the soil.
\end{abstract}

Keywords: Caatinga, Johansen model, soil heat flux.

\section{Impacto do cultivo da palma forrageira (O. Ficus-Indica) nas características térmica do solo}

\section{RESUMO}

A temperatura é um fator de fundamental importância para o entendimento dos processos físicos, químicos e biológicos que ocorrem no solo. Entretanto, existem poucos estudos na zona semiárida brasileira que buscam compreender como a degradação dos solos afetam as suas características térmicas. $\mathrm{O}$ objetivo deste estudo foi avaliar a influência das técnicas de cultivo na caracterização térmica de um solo, utilizando o modelo proposto por Johansen. O estudo foi conduzido em duas parcelas, uma com 2,0 hectare de solo com mata nativa (Caatinga) e a outra com 4,5 hectare de solo cultivado com Palma Forrageira (O. ficus-indica), no Município de São Bento do Una - PE, na mesorregião do Agreste Meridional do estado de Pernambuco. Observou-se que os procedimentos utilizados no preparo para o cultivo da Palma Forrageira ocasionaram uma diminuição na capacidade de transmissão da temperatura superficial para o interior do solo. As mudanças nas propriedades físicas do solo, necessárias para o cultivo ocasionaram em uma redução no valor médio da capacidade térmica volumétrica do solo em 
cerca de 22\%; um aumento de aproximadamente 5\% na média da capacidade térmica volumétrica e um aumento de $26 \%$ na difusividade térmica do solo, além de uma redução de aproximadamente $50 \%$ no fluxo de calor no solo a partir da superfície.

Palavras-chave: Caatinga, modelo Johansen, fluxo de calor no solo.

\section{INTRODUCTION}

Soil is a vital part of the environment. It influences the distribution of plant species and provides a habitat for a wide range of organisms. It acts as a filtration system for surface water and chemical substances between the atmosphere and the earth. The soil is relevant to the fate of human society due to the services, goods and resources it gives to the humankind. It reacts to the changes in vegetative cover with changes in soil erosion, runoff, water conservation and temperature, among others (Keesstra et al., 2016; Van Hall et al., 2016).

Temperature is a fundamentally important factor for understanding the physical, chemical and biological processes that occur in the soil. However, there are few studies in the Brazilian semiarid zone that seek to understand how soil degradation affects its thermal characteristics. The changes in these characteristics may compromise the germination of some plant species, both in speed and in the percentage of germination, making regrowth of the original vegetation impossible.

The Caatinga biome is dominant in the Brazilian semiarid zone, covering an area of approximately 845 thousand square kilometers, equivalent to $11 \%$ of the national territory. However, it is the third most-degraded biome in Brazil, behind those of the Atlantic Forest and the Cerrado. This is mainly due to accelerated deforestation, sometimes for the cutting of firewood, sometimes for conversion to pasture and agriculture (Beuchle et al., 2015; Gariglio et al., 2010; Myers et al., 2000).

To understand the propagation, storage and diffusion of heat in the soil, it is necessary to determine its thermal properties, which result from a set of factors that must be determined on site. Among them are volumetric water content, porosity, density, and quartz content (Farouki, 1981, Dong et al., 2015).

Silva et al. (2011) evaluated the behavior of thermal conductivity in caatinga vegetation with predominance of cacti, in the State of Paraíba. For this, they utilized three methodologies. Two were based on multiple regression (linear and polynomial) and the harmonic method. They concluded that the multiple linear regression model, based on surface temperature and time, showed the best results. They also observed that thermal conductivity on surfaces with cactus vegetation behaved as an insulator in the daytime period and as a conductor during the nighttime.

Silans and Werlang (2011), analyzed the thermodynamic properties of soil and soil-water dynamics in the semi-arid region of Brazil, in the Caatinga dos Cariris region of Paraíba, and observed that the isothermal diffusion coefficient is greater than that of isopotential diffusion when soil is moist, and the reverse is true when the soil is dry, influencing the evaporation of water from the soil, which is reduced in the diurnal period.

Soares (2013) used the harmonic method to estimate the thermal diffusivity of the soil and the heat flux at the surface and at depth in a Yellow Latosol in the semi-arid zone of Paraíba cultivated with castor beans, and found quite satisfactory results when compared with values measured in the field with flux meters.

Oliveira et al. (2015) analyzed thermal diffusivity using six algorithms (Amplitude, Arc Tangent, Conduction-Convection, Finite Differences, Phase, and Logarithm) and concluded that Arc Tangent and Conduction-Convection algorithms produced the best results. Maciel Neto et al. (2015) used the harmonic and logarithmic methods on two types of soils from the 
Southern Agreste region of the State of Pernambuco (Yellow Latosol and Regolithic Neosol) and concluded that the thermal diffusivity values provided by both methods fell within the limits established in the literature, showing their efficiency.

Souza et al. (2016) evaluated the effect of removal of vegetation on the soil temperature in the Cariris Velhos, PB region, using a historical series of temperature data and satellite images. The authors concluded that deforestation resulted in an elevation of the average temperature of the soils, with levels above $35^{\circ} \mathrm{C}$ found over a large part of the region, making the natural recovery of these environments impossible.

Różański and Stefaniuk (2016) evaluated some of the estimates for the thermal conductivity of saturated clay soils using five models widely known in the literature (1966; and Johansen 1975). They concluded that although the model proposed by Johansen is simple, its capacity to represent the thermal conductivity of the soil was quite satisfactory, providing the best prediction when compared to the laboratory-obtained data.

The objective of this work was to quantify the influence of spineless cactus (O. ficusindica) cultivation on the thermal characteristics of a soil originally covered with native forest (Caatinga), using the model proposed by Johansen.

\section{MATERIAL AND METHODS}

The study was conducted at the Santos e Silva farm in the municipality of São Bento do Una in the Southern Agreste region of the state of Pernambuco, $199 \mathrm{Km}$ from the Capital (Figure 1), between September and October 2016. The coordinates are: $8^{\circ} 36^{\prime} 37^{\prime \prime}$ South latitude and $36^{\circ} 21^{\prime} 45^{\prime \prime}$ West longitude at an altitude of $621 \mathrm{~m}$. The soil of the study area is classified as Lithic Neosol and the local relief is gently sloped with a mean slope of $1.6 \%$. The semi-arid climate predominates, with a hot, dry summer and a rainy season between the months of April and June. According to the climate classification of Köppen-Geiger, the climate is classified as BSh. The average annual precipitation does not exceed $300 \mathrm{~mm}$ and the natural vegetation is composed of hyper-xerophilic caatinga. The analyzed plots consisted of 2.0 ha of soil with native forest (Caatinga) and 4.5 ha of soil cultivated with spineless cactus ( $O$. ficus-indica).

Of the 2 ha of Caatinga, although the plants are xerophiles, the scarcity of rainfall over the last five years has drastically reduced their vegetative density. In this area, the predominant arboreal vegetation is composed mainly of black jurema (Mimosa hostilis Benth.), white jurema (Mimosa hostilis) and more rarely umbuzeiro (Spondias tuberosa). Among the cacti found were the foxtail (Harrisia adscendens), the woodpecker (Pilosocereus catingicola), the mandacaru (Cereus jamacaru) and the xique-xique (Pilosocereus gounellei). The soil is compacted, shallow, and stony, with fragments of rock on the surface. At a depth of $0.4 \mathrm{~m}$, it becomes impossible to excavate without the use of machinery, due to the large quantity of rocks.

Of the 4.5 ha of soil cultivated with spineless cactus ( $O$. ficus-indica), along with the cultivation, a large and diverse amount of weeds can be seen, which are periodically removed. Due to the scarcity of water, the crop does not grow satisfactorily. The leaves are small, twisted, and largely a non-characteristic color with a yellowish tint. Fertilization is carried out at the beginning of planting and is not repeated until the time of harvest. Initially, the distance between plants is approximately $0.5 \mathrm{~m}$. Between lines, the distance is about $1.0 \mathrm{~m}$. Both distances decrease as the crop grows. Due to the treatment necessary for cultivation, the soil is not compacted nor does it contain rocky fragments within the upper $0.4 \mathrm{~m}$ of its depth.

Soil samples with a non-deformed structure were collected in the 0.0 to $0.2 \mathrm{~m}$ depth layer in two distinct areas: fifteen samples under Caatinga and twenty-five samples under cultivation of spineless cactus (O. ficus-indica), in order to determine soil density, residual and saturated volumetric masses, as well as deformed samples for granulometric analysis. 


\subsection{Johansen thermal conductivity model}

Johansen (1975) proposed a model to estimate the thermal conductivity of soil $(\lambda)$ as a function of its value for dry soil $\left(\lambda_{d r y}\right)$ and saturated soil $\left(\lambda_{s a t}\right)$, considering the mineral composition, global density, particle density, and Kersten number $\left(K_{e}\right)$, Equation 1:

$\lambda=\left(\lambda_{\text {sat }}-\lambda_{\text {dry }}\right) K_{e}+\lambda_{d r y}$

The Kersten number $\left(K_{e}\right)$ is expressed for coarse and fine textured soils, by the following (Equation 2):

$K_{e}= \begin{cases}0.7 \log S_{e}+1, & \left(S_{e}>0.05\right) \\ 1.0 \log S_{e}+1, & \left(S_{e}>0.10\right)\end{cases}$

With $S_{e}$ being the effective degree of saturation of the soil.

Originally, $S_{e}$ did not consider residual water content; however, in this study Silans and Werlang's (2011) expression was used, which adjusted for the experimental conditions of the paraiban Cariri, making a correction for the relative volumetric water content, using the expression usually used in the models to characterize the retention curve and hydraulic conductivity (Equation 3):

$S_{e}=\frac{\theta-\theta_{r}}{\theta_{s}-\theta_{r}}$

With $\theta, \theta_{r}$, and $\theta_{s}$ being the volumetric, residual, and saturated water content, respectively.

Through observation of the Kersten number acceptance criteria, the minimum volumetric water content $\left(\theta_{\min }\right)$, is defined for thick and fine textured soils, respectively, by (Equation 4):

$\theta_{\text {min }}=\left\{\begin{array}{l}\frac{\theta_{s}+19 \theta_{r}}{20} \\ \frac{\theta_{s}+9 \theta_{r}}{10}\end{array}\right.$

Johansen developed semi-empirical equations to calculate the thermal conductivity of dry and saturated soil (Equations 5 and 6):

$\lambda_{d r y}=\frac{0.135 p_{b}+64.7}{2700-0.947 p_{b}}$

$\lambda_{s a t}=\lambda_{s}^{1-n} \lambda_{w}^{n}$

Where $p_{b}$ is the dry soil density $\left(\mathrm{kg} \mathrm{m}^{-3}\right), 2700$ is the soil particle density, $n$ is the soil porosity, $\lambda_{w}$ is the thermal conductivity of water, and $\lambda_{s}$ is the effective thermal conductivity of bulk soil, as determined by Equation 7:

$\lambda_{s}=\lambda_{o}^{1-q} \lambda_{q}^{q}$

Where $\lambda_{q}$ and $\lambda_{o}$ are the thermal conductivities of quartz and other minerals, respectively, and $q$ is the quartz content. The measurement of quartz content is not commonly performed. In practice, when dealing with silica sands, it is often assumed that quartz content $q$ is equal to the content of sand (Peters-Lidard et al., 1998; Różański and Stefaniuk 2016). 


\subsection{Volumetric heat capacity of the soil}

The volumetric heat capacity of a soil $(C)$ is defined as the amount of heat required to raise the temperature of $1 \mathrm{~cm}^{3}$ of soil by $1^{\circ} \mathrm{C}$. The volumetric heat capacity depends on the composition of the solid material of the soil (mineral and organic constituents), the soil density, and volumetric water content.

The value of $\mathrm{C}\left(\mathrm{MJ} \mathrm{m}^{-3}{ }^{\circ} \mathrm{C}^{-1}\right)$ was estimated by Equation 8:

$C=1,92(1-\varphi)+4,18 \theta$

Where $\varphi$ is the porosity and $\theta$ is the water content of the soil (Zhang et al., 2014).

\subsection{Thermal diffusivity of the soil}

The thermal diffusivity of the soil $(\alpha)$ can be defined as a measure of the temperature variation produced in a unit of volume when a quantity of heat passes through this volume in a unit of time, when a unit temperature gradient is imposed on two opposite sides of the volume. The term thermal diffusivity was first used by Lord Kelvin. It can be calculated as the quotient between the thermal conductivity of the soil and the volumetric heat capacity of the soil, as shown by Equation 9:

$\alpha=\frac{\lambda_{s}}{C}$

\subsection{Soil temperature modeling}

The temperature of the soil presents a behavior that depends on variations in several atmospheric variables that modify the energy processes on the surface of the soil, such as solar radiation, cloudiness, and wind speed, among others. The simplest way to model soil temperature is to use a time-dependent sine wave equation, i.e., the temperature $(T)$ at depth $\mathrm{z}$ can be calculated by Equation 10:

$T=\bar{T}+A e^{-\frac{z}{D}} \operatorname{sen}(\omega t-z / D+\Phi)$

Where $\bar{T}$ is the average temperature at the surface of the soil, $A$ is the amplitude of the thermal oscillation, $\Phi$ the phase of the thermal wave, and $\omega$ is the angular velocity of the Earth's rotation, expressed by (Equation 11):

$D=\sqrt{2 \alpha / \omega}$

The velocity of the propagation of the temperature wave $(V)$, which expresses the speed with which the wave propagates in the soil, is obtained by the Equation 12:

$V=\sqrt{2 \omega \alpha}$

The surface temperature of the soil can be estimated by the Equation 13:

$T_{0}=\bar{T}+A \operatorname{sen}(\omega t+\Phi)$

The soil heat flux can be defined as the amount of heat flowing through the soil per unit area and unit time, determining the thermal environment of the soil (Fuchs, 1986). It can be estimated by differentiating equation 10 with respect to $z$, and combining the result with equations 9 and 13, where we find (Equation 14): 
$G=A C \sqrt{\omega \alpha} e^{-\frac{z}{D}} \operatorname{sen}\left(\omega t+\Phi+\frac{\pi}{4}-\frac{z}{D}\right)$

This equation represents the heat flux $(G)$, a positive value representing a downward direction, in a homogeneous soil profile, with the surface temperature described by a sinusoidal function.

\section{RESULTS AND DISCUSSION}

There were no significant differences between the values of soil-size fractions under the Caatinga and under the spineless cactus. This was expected, as it was the same soil. The soil contains a percentage of sand much higher than the values found for silt and for clay. For the soil under the Caatinga, the sand percentages were between $68.1 \%$ and $80.4 \%$, with an average of $73.2 \%$. For the soil under the spineless cactus, the sand percentage values were between $68.1 \%$ and $79.7 \%$, with an average value of $74.1 \%$. The highest value found for the percentage of silt, both for the soil under the Caatinga and for the soil under the spineless cactus, was $18.4 \%$. The minimum values were $11.8 \%$ and $9.2 \%$, respectively. The mean values were $15.8 \%$ for the soil under the Caatinga, and $15 \%$ for the soil under the spineless cactus. The percentages of clay were within the same range of values, both for the soil under the Caatinga and for the soil under the spineless cactus, with a minimum value of $8.5 \%$ and a maximum of $15.1 \%$. The averages differed only slightly, with values of $11 \%$ and $10.9 \%$, respectively.

Table 1 presents the values for residual $\left(\theta_{r}\right)$ and saturated $\left(\theta_{s}\right)$ volumetric water content, porosity $(\varphi)$, quartz content $(q)$ and soil density $\left(p_{b}\right)$ values of the soils under the Caatinga and those cultivated with spineless cactus.

In contrast to the equality found in the grain size fractions, the values of residual and saturated water content show considerable differences between the soils under the Caatinga and under the spineless cactus. Considering the soil under the Caatinga as reference, we observed that $\theta_{r}$ and $\theta_{s}$ increased approximately $97 \%$ and $27 \%$, respectively. The porosity of the soil increased by $27 \%$ and the $q$ and $p_{b}$ had reductions of about $5 \%$ and $15 \%$, respectively.

Table 1. Values of residual $\left(\theta_{r}\right)$ and saturated $\left(\theta_{s}\right)$ volumetric water content, porosity $(\varphi)$, quartz content $(q)$ and soil density $\left(p_{b}\right)$ with Caatinga and cultivated with spineless cactus.

\begin{tabular}{ccc}
\hline Parameter & Caatinga & Spineless cactus \\
\hline$\theta_{r}\left(\mathrm{~cm}^{3} \mathrm{~cm}^{-3}\right)$ & 0.033 & 0.065 \\
$\theta_{s}\left(\mathrm{~cm}^{3} \mathrm{~cm}^{-3}\right)$ & 0.344 & 0.437 \\
$\varphi$ & 0.362 & 0.460 \\
$q$ & 0.732 & 0.741 \\
$p_{b}\left(\mathrm{~kg} \mathrm{~m}^{-3}\right)$ & 1690 & 1430 \\
\hline
\end{tabular}

The thermal conductivity values of the soil under the Caatinga and under the spineless cactus, as a function of the soil volumetric water content, are presented in Figure 1. It can be observed that the values of $\lambda$ increased logarithmically with the volumetric water content of the soil. However, Dong et al. (2015) noted that the Johansen model underestimates the thermal conductivity at lower saturation and overestimates at higher saturation.

For the soil under the Caatinga, the thermal conductivity values ranged from $0.71 \mathrm{~W} \mathrm{~m}^{-1} \mathrm{~K}^{-1}$ to $2.4 \mathrm{~W} \mathrm{~m}^{-1} \mathrm{~K}^{-1}$. As for the soil under the spineless cactus, the values ranged from $0.41 \mathrm{~W} \mathrm{~m}^{-1} \mathrm{~K}^{-1}$ to $1.89 \mathrm{~W} \mathrm{~m}^{-1} \mathrm{~K}^{-1}$. The average values were $1.74 \mathrm{~W} \mathrm{~m}^{-1} \mathrm{~K}^{-1}$ and $1.36 \mathrm{~W} \mathrm{~m}^{-1} \mathrm{~K}^{-1}$, respectively. 
Both minimum values are within the acceptable range. However, in order to reduce the effect of the proximity between the volumetric water content and the saturated volumetric water content, the limits for volumetric water content should be 0.12 and 0.14 for soil planted with Caatinga and that cultivated with spineless cactus, respectively (Soares, 2016).

The higher values of volumetric water content increased thermal conductivity. Increasing water content in sand perhaps completed water films around the larger sand particles, thus increasing the contact area between sand particles, which caused the thermal conductivity to increase rapidly, corroborating with Abu-Hamdeh (2003).

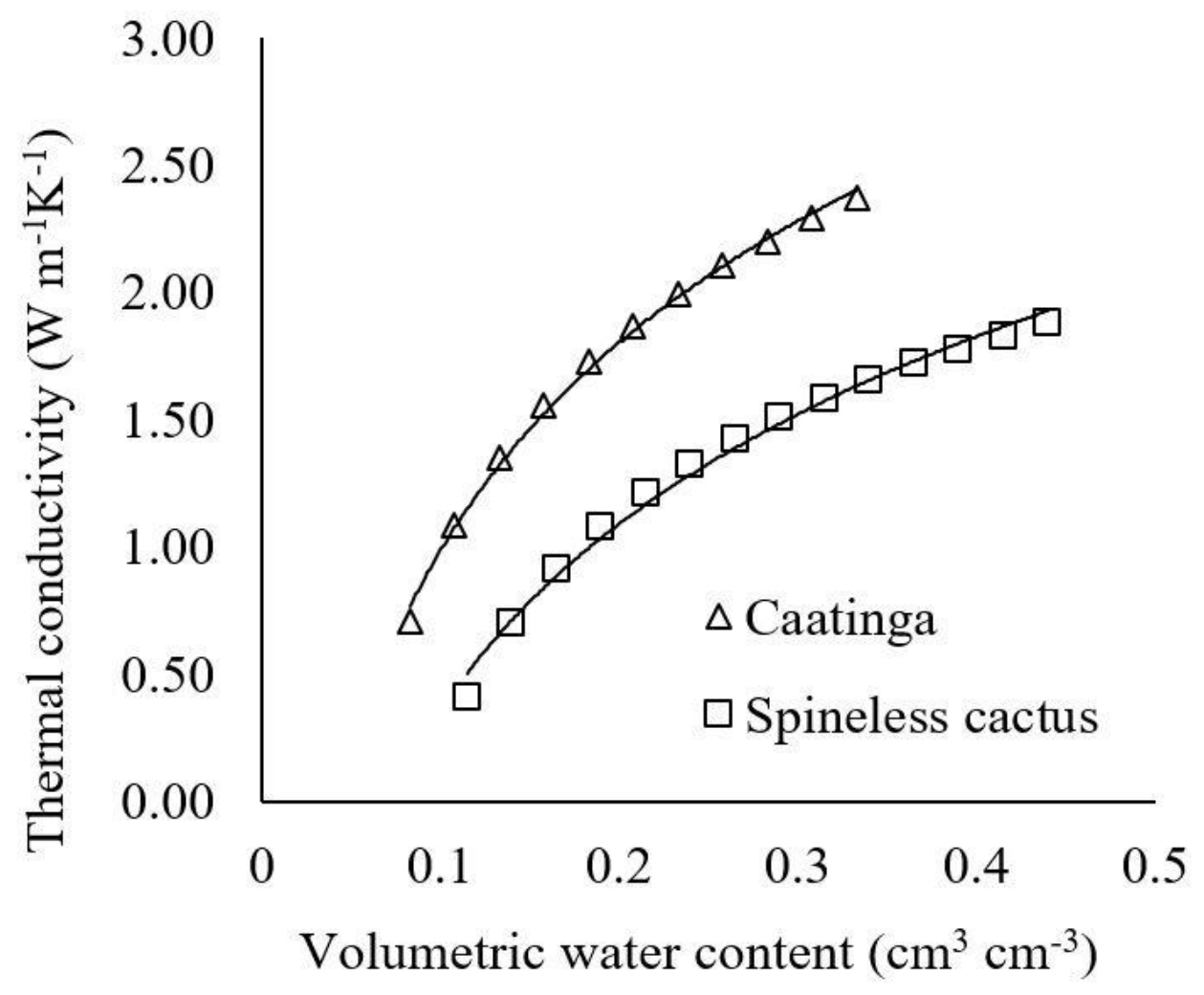

Figure 1. Thermal conductivity of the soil under the Caatinga and the spineless cactus.

Using the values calculated by the methodology proposed by Johansen, it was possible to obtain a satisfactory interpolation of $\lambda$ as a function of the volumetric water content, both for the soil under the Caatinga (Equation 15):

$\lambda=1,18 \ln (\theta)+3,70$

With a value of $\mathrm{r}^{2}=0,997$, as well as with the soil under the spineless cactos (Equation 16):

$\lambda=1,06 \ln (\theta)+2,80$

With a value of $r^{2}=0,992$

The values for volumetric heat capacity of the soil under the Caatinga and under the spineless cactus, as a function of soil volumetric water content, are presented in Figure 2. The slopes of the curves for the two soils are practically the same.

As expected, the $C$ values increased linearly with soil volumetric water content in both cases. For the Caatinga, the volumetric heat capacity values ranged from $1.78 \mathrm{MJ} \mathrm{m}^{-1} \mathrm{~K}^{-1}$ to $2.83 \mathrm{MJ} \mathrm{m}^{-1} \mathrm{~K}^{-1}$. For the spineless cactus, the values went from $1.74 \mathrm{MJ} \mathrm{m}^{-1} \mathrm{~K}^{-1}$ to 
3.10 $\mathrm{MJ} \mathrm{m}^{-1} \mathrm{~K}^{-1}$. The mean values were $2.31 \mathrm{MJ} \mathrm{m}^{-1} \mathrm{~K}^{-1}$ and $2.42 \mathrm{MJ} \mathrm{m}^{-1} \mathrm{~K}^{-1}$, respectively. Volumetric heat capacity decrease with decrease bulk density as a result of particle contact enhancement as porosity is decreased, and because of greater mass of solids per unit volume (Abu-Hamdeh, 2003).

The higher C-value indicates that the soil cultivated with spineless cactus has a greater capacity to store heat. As the particle sizes are equivalent, this capacity must be derived from greater porosity, which allows for a greater amount of water to be retained by the soil. As is known, the C-value for water is higher than that for other components of the soil.

The values of evolution of thermal diffusivity as a function of volumetric soil volumetric water content under the Caatinga and under the spineless cactus are presented in Figure 3. In general, higher values of thermal diffusivity are observed with increasing soil volumetric water content. However, this increase is not linear, as expected.

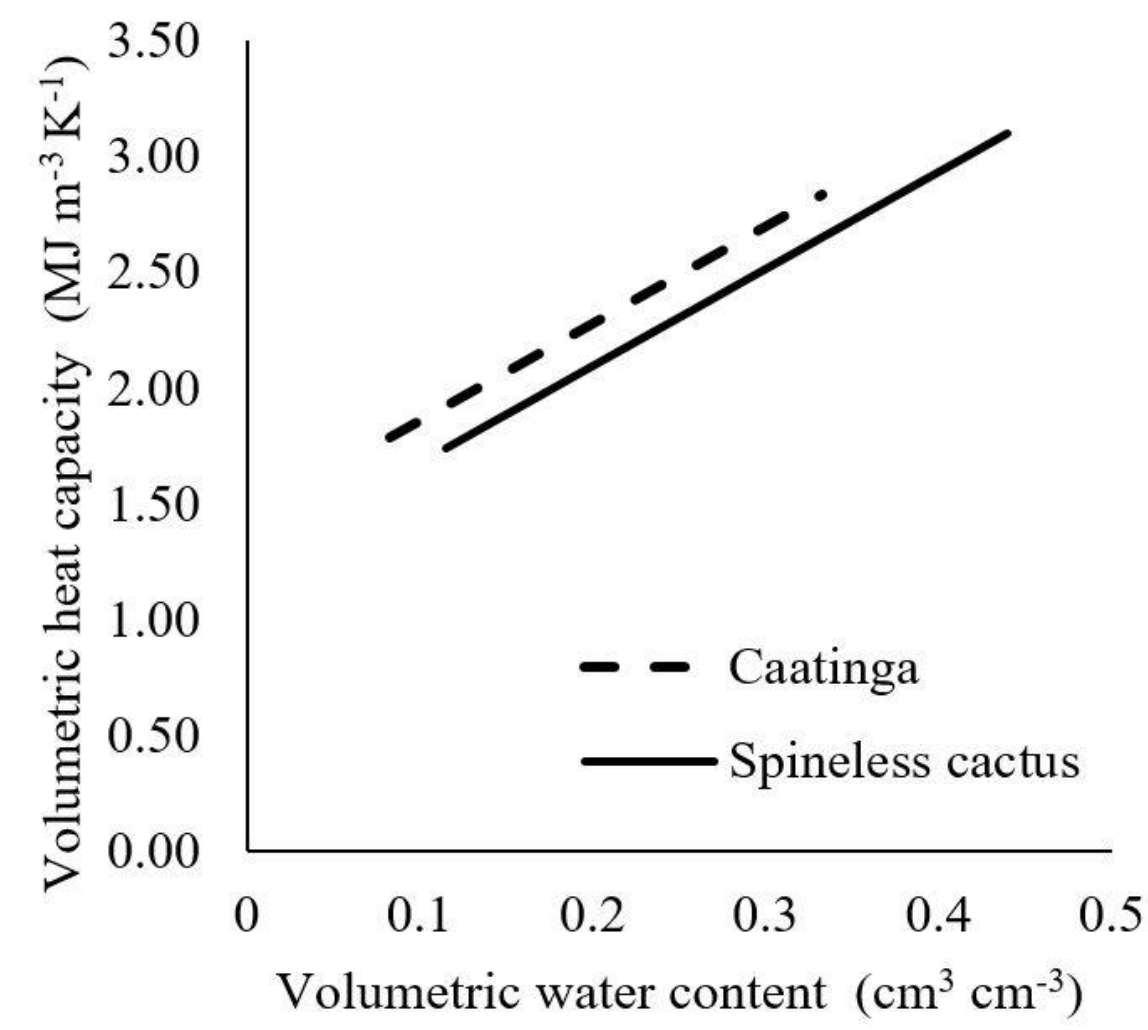

Figure 2. Volumetric heat capacity of the soil under the Caatinga and under the spineless cactus.

When the thermal diffusivity reaches a certain value (approximately $8.4 \mu \mathrm{m} 2 \mathrm{~s}-1$ for the soil under the Caatinga and $6.1 \mu \mathrm{m} 2 \mathrm{~s}-1$ for the soil under the spineless cactus), even if the soil volumetric water content increases, the thermal diffusivity remains almost unchanged. For the soil under the Caatinga, the thermal diffusivity values of the soil varied between $3.96 \mu \mathrm{m} 2 \mathrm{~s}-1$ and $8.41 \mu \mathrm{m} 2 \mathrm{~s}-1$, with an average value of $7.43 \mu \mathrm{m} 2 \mathrm{~s}-1$. For the soil under the spineless cactus, the values ranged from $2.35 \mu \mathrm{m} 2 \mathrm{~s}-1$ to $6.18 \mu \mathrm{m} 2 \mathrm{~s}-1$, with an average value of $5.47 \mu \mathrm{m} 2 \mathrm{~s}-1$. Soil management practices led to a reduction in $\alpha$-values of approximately $25 \%$.

The diffusivity peak in both cases might be caused by the relative changes in thermal conductivity and volumetric heat capacity of the soil. Before the peak value of thermal diffusivity, it seems an increase in thermal conductivity with an increase in volumetric water content was relatively greater than in volumetric heat capacity. However, after the peak, the relative increase in thermal conductivity of soil was perhaps lower than the constant increase in volumetric heat capacity (Abu-Hamdeh, 2003; Soares 2016). 


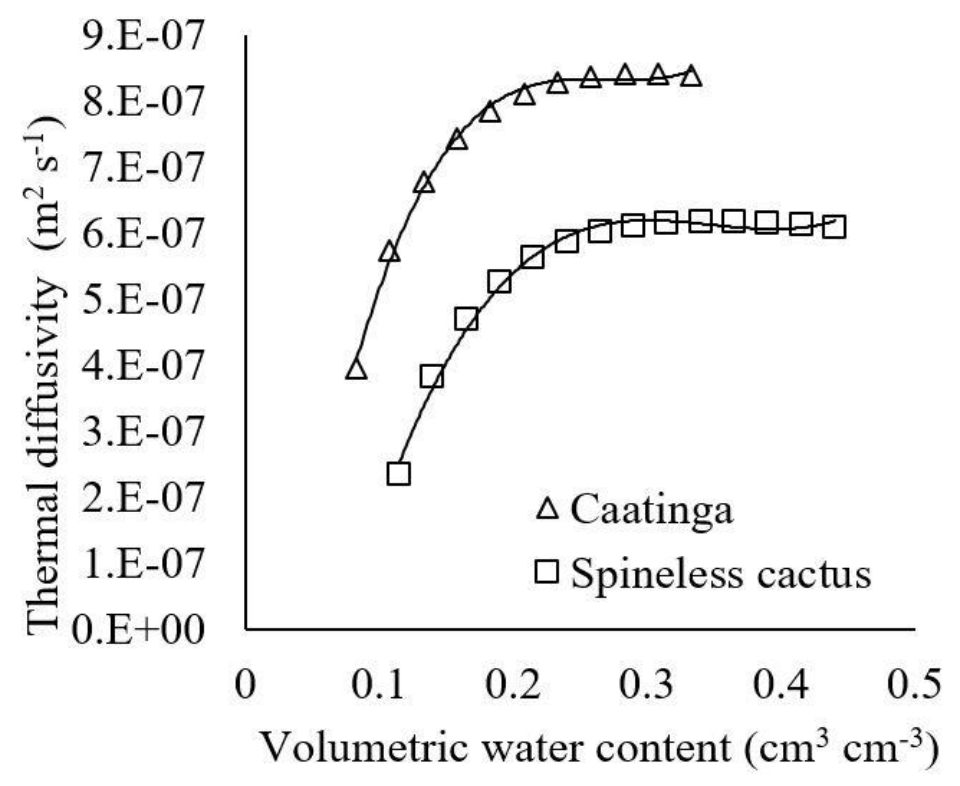

Figure 3. Thermal diffusivity of the soil with native forest (Caatinga) and with spineless cactus.

Using the values calculated by Equation 9, the following mathematical equations for the thermal diffusivity of the soil were obtained, for the Caatinga (Equation 17):

$\alpha=\frac{7 \theta^{3}-5 \theta^{2}+\theta-0,05}{10^{5}}$

and for the spineless cactus (Equation 18):

$\alpha=\frac{3 \theta^{3}-3 \theta^{2}+\theta-0,07}{10^{5}}$

Where $\alpha$ is the thermal diffusivity, in $\mathrm{m}^{2} \mathrm{~s}^{-1}$, and $\theta$ is the volumetric water content, as a percentage. In both cases the coefficient of determination was higher than 0.99 .

Figure 4 shows the soil temperature profile of the Caatinga and the spineless cactus, on September 27, 2016, at 12 o'clock. In both cases, the temperature was satisfactorily modeled by the sinusoidal function. It is observed that the amplitude of the thermal wave of the soil cultivated with spineless cactus suffers a lag when compared to that of Caatinga. This occurred at all depths evaluated. The highest and lowest lag values were $0.51^{\circ} \mathrm{C}$ and $0.40^{\circ} \mathrm{C}$, at the depths of $0.10 \mathrm{~m}$ and $0.40 \mathrm{~m}$, respectively.

On September 28, the maximum soil temperature under the Caatinga, at depths of $0.05 \mathrm{~m}$ and $0.40 \mathrm{~m}$ was $33.98^{\circ} \mathrm{C}$ and $31.62^{\circ} \mathrm{C}$, respectively, representing a reduction of $2.36^{\circ} \mathrm{C}$, corresponding to approximately 7\%. Similarly, in the soil cultivated with spineless cactus, temperatures at the same depths presented a difference of approximately $6 \%$. This reduction resulted from low soil volumetric water content values during the simulation period, which in turn resulted in lower values of thermal soil diffusivity, leaving it with higher surface temperatures that decay rapidly with depth.

Differences in temperature values are mainly explained by differences in residual water content values, and secondarily by differences in quartz content, saturated water content, and soil density (Soares, 2016).

In the daily soil thermal cycle under the Caatinga, the depth of damping and the propagation speed were $0.13 \mathrm{~m}$ and $6.14 \mu \mathrm{m} \mathrm{s}^{-1}$, respectively. These values differed from those found for soil cultivated with spineless cactus, which presented a value of $0.8 \mathrm{~m}$ for the damping 
depth and a value of $5.86 \mu \mathrm{m} \mathrm{s}^{-1}$ for the velocity of propagation of the thermal wave, about $8 \%$ smaller.

During the simulation period, the soil heat flux in the had a maximum value of $39.96 \mathrm{~W} \mathrm{~m}^{-2}$ for the soil under the Caatinga and $20.78 \mathrm{~W} \mathrm{~m}^{-2}$ for the soil cultivated with spineless cactus. At night, when the heat flux moves from the interior of the soil towards the surface, the minimum values determined were $-49.64 \mathrm{~W} \mathrm{~m}^{-2}$ and $-20.84 \mathrm{~W} \mathrm{~m}^{-2}$ for the soil under the Caatinga and that cultivated with spineless cactus, respectively. The procedures performed for the cultivation of spineless cactus reduced the thermal behavior of the soil by almost $50 \%$ in the daytime period and by almost $60 \%$ during the nocturnal period. The decrease in the values of the soil heat flux is due to the increase in the values of residual water content, due to soil management techniques for cultivation of spineless cactus. This corroborates the results found by Soares (2016), which have demonstrated that for a same value of volumetric water content, the increase of the residual volumetric water content causes a decrease of the thermal conductivity of soil, and, consequently, of soil heat flux.

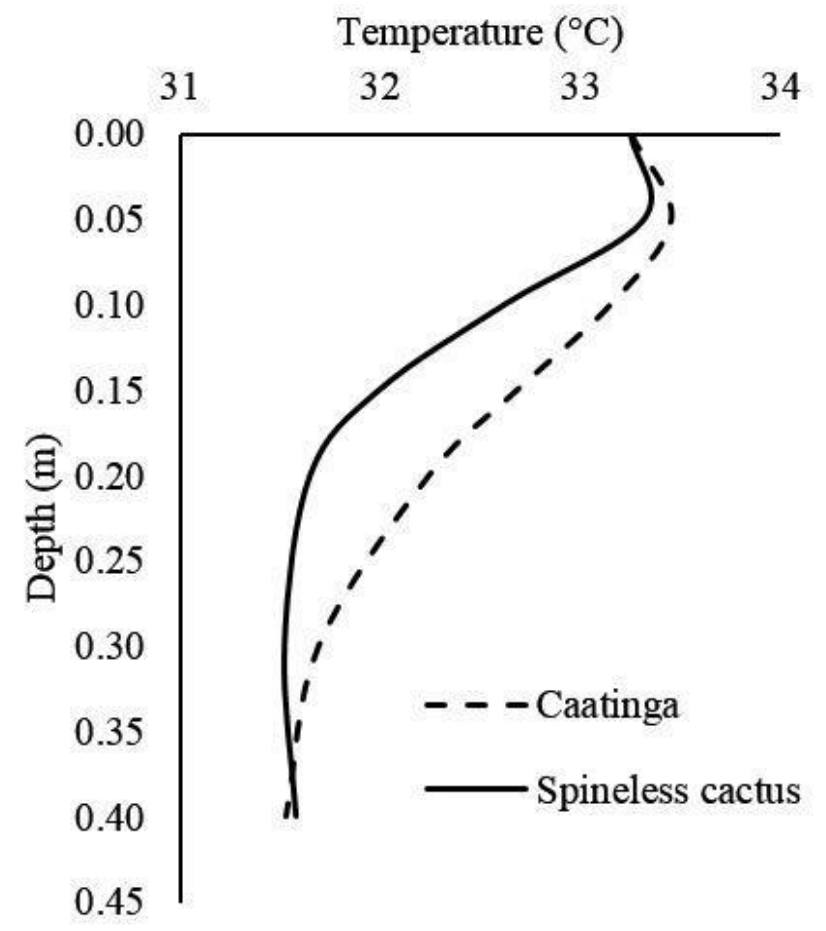

Figure 4. Soil temperature profile of the Caatinga and the spineless cactus, on September 27, 2016, at 12 o'clock.

\section{CONCLUSION}

This study of the effects of vegetation cover change on native Brazilian semi-arid vegetation was evaluated using the model provided by Johansen.

The procedures used to prepare the soil for spineless cactus cultivation caused an increase in the residual and saturated volumetric water content and porosity in addition to a reduction in the and soil density and, consequently, a reduction in the transmission capacity of the surface temperature to the interior of the soil.

The cultivation of the spineless cactus caused a reduction in the average volumetric heat capacity of the soil of about $22 \%$, an increase of approximately $5 \%$ in the average heat capacity volume, and a $26 \%$ increase in the thermal diffusivity of the soil. Changes in soil for spineless cactus cultivation reduced soil heat flux by almost $50 \%$. 


\section{ACKNOWLEDGEMENTS}

The author thanks the Foundation for Support of Science and Technology of the State of Pernambuco - FACEPE, for financial support through research assistance (APQ 0582-01/15).

\section{REFERENCES}

ABU-HAMDEH, N. H. Thermal Properties of Soils as affected by Density and Water Content. Biosystems Engineering, v. 86 n.1, p. 97-102, 2003. http://dx.doi.org/10.1016/S15375110(03)00112-0

BEUCHLE, R.; GRECCI, R. C.; SHIMABUKURO, Y. E.; SELIGER, R.; EVA, H. D.; SANO, E. et al. Land cover changes in the Brazilian Cerrado and Caatinga biomes from 1990 to 2010 based on a systematic remote sensing sampling approach. Applied Geography, v. 58, p. 116-127, 2015. https://doi.org/10.1016/j.apgeog.2015.01.017

DONG, Y.; MCCARTNEY, J. S.; LU, N. Critical review of thermal conductivity models for unsaturated soils. Geotechnical and Geological Engineering, v. 33, n 2, p. 207-221, 2015. https://doi.org/10.1007/s10706-015-9843-2

FAROUKI, O. T. Thermal Properties of Soils. 1981. 136p. Monograph - Cold Regions Science and Engineering, Hanover, 1981.

FUCHS, G. CO2 fixation in acetogenic bacteria: Variations on a theme. FEMS Microbiology Letters, v. 39, n. 3, p. 181-213, 1986. https://doi.org/10.1016/0378-1097(86)90446-5

GARIGLIO, M. A.; SAMPAIO, E. V. S. B.; CESTARO, L. A.; KAGEYAMA, P. Y. Uso sustentável e conservação dos recursos florestais da caatinga. Brasília, DF: Serviço Florestal Brasileiro, 2010. 368 p.

JOHANSEN, O. Thermal conductivity of soils. Tese (Doutorado) - University of Trondheim, Trondheim, 1975.

KEESSTRA, S.; PEREIRA, P.; NOVARA, A.; BREVIK, E. C.; AZORIN-MOLINA, C.; PARRAS-ALCÁNTARA, L. et al. Effects of soil management techniques on soil water erosion in apricot orchards. Science of the Total Environment, v. 551, p.357-366, 2016. http://dx.doi.org/10.1016/j.scitotenv.2016.01.182

MACIEL NETO, J. A.; ANTONINO, A. C. D.; LIMA, J. R. S.; SOUZA, E. S.; SOARES, W. A.; ALVES, E. M. et al. Caracterização térmica de solos no agreste meridional do estado de Pernambuco, Brasil. Revista Brasileira de Geografia Física, v. 8, n. 1, p. 167-178, 2015.

MYERS, N.; MITTERMEIER, R. A.; MITTERMEIER, C. G.; FONSECA, G. A. B; KENT, J. Biodiversity hotspots for conservation priorities. Nature, v. 403, p.853-859, 2000. http://dx.doi.org/10.1038/35002501

OLIVEIRA, D. B. C.; ALBUQUERQUE NETO, N. A.; SOARES, W. A. Análise de metodologias na determinação da difusividade térmica do solo. Diálogos: Revista de Estudos Linguísticos, Literários, Culturais e da Contemporaneidade, v. 12, p. 282-297, 2015.

PETERS-LIDARD, C. D.; BLACKBURN, E.; LIANG, X.; WOOD, E. F. The effect of soil thermal conductivity parameterization on surface energy fluxes and temperatures. Journal of the Atmospheric Sciences, v. 55, n. 7, p. 1209-1224, 1998. https://doi.org/10.1175/15200469(1998)055<1209:TEOSTC>2.0.CO;2 
RÓŻAŃSKI, A.; STEFANIUK, D. On the prediction of the thermal conductivity of saturated clayey soils: effect of the specific surface area. Acta Geodynamicaet Geomaterialia, v. 13, n. 4, p. 339-349, 2016. http://dx.doi.org/10.13168/AGG.2016.0016

SILANS, A. M. P.; WERLANG, L. M. Dinâmica da umidade de um solo da Caatinga em função de sua condutividade térmica. Revista Brasileira de Engenharia Agrícola e Ambiental, v. 15, n. 9, p. 950-958, 2011.

SILVA, F. M.; ANDRADE, A. P.; FERNANDES, P. D. COSTA, A. M. B. Modelagem da condutividade térmica em área de caatingacom predominância de cactáceas. Revista Caatinga, v. 24, n. 2, p. 113-120, 2011.

SOARES, W. A. Análise comparativa do fluxo de calor no solo em profundidade e na superfície. Revista Brasileira de Geografia Física, v. 6, n. 4, p. 665-679, 2013.

SOARES, W. A. Efeitos das propriedades físicas do solo na estimativa da condutividade térmica. Revista Brasileira de Geografia Física, v. 9, n. 6, p. 1657-1667, 2016.

SOUZA, B. I.; MACÊDO, M. L. A.; SILVA, G. J. F. Temperatura dos solos e suas influências na regeneração natural da caatinga nos Cariris Velhos - PB. Revista Raega - O Espaço Geográfico em Análise, v. 4, n, 3, p. 261-287, 2016. http://dx.doi.org/10.5380/raega.v35i0.41609

VAN HALL, R. L.; CAMMERAAT, L. H.; KEESSTRA, S. D.; ZORN, M. Impact of secondary vegetation succession on soil quality in a humid Mediterranean landscape. Catena, v. 149, p. 836-843, 2016. http://dx.doi.org/10.1016/j.catena.2016.05.021Villacís

ZHANG, X.; HEITMAN, J.; HORTON, R.; REN, TUSHENG. Measuring Near-Surface Soil Thermal Properties with the Heat-Pulse Method: Correction of Ambient Temperature and Soil-Air Interface Effects. Soil Science Society of America Journal, v. 78, p. 1575 - 1583, 2014. https://doi.org/10.2136/sssaj2014.01.0014 